\title{
The Roles of Social Support in Promoting Adolescents' Classroom Cognitive Engagement Through Academic Self-Efficacy
}

\author{
SHARIFAH AZIZAH SYED SAHIL \\ Insaniah University College \\ sharifahazizah@yahoo.com \\ ROSNA AWANG HASHIM \\ College of Arts and Sciences \\ Universiti Utara Malaysia \\ rosna@uum.edu.my
}

\begin{abstract}
Purpose - The main aim of the present investigation was to examine the role of teacher, peer, and parental academic and emotional support in predicting adolescent cognitive engagement, especially within the context of ESL classrooms.

Method - The present study examined the availability of academic and emotional support from teachers, classmates and parents as perceived by adolescents, via instruments which were adapted from a number of established measures. This cross-sectional study utilized the survey method, and a total of 450 adolescents from 11 secondary schools in Malaysia, representing early and middle adolescence, took part in the survey. The study assessed each source of support namely teacher, peers and parents within one model.
\end{abstract}

Findings - Findings from the structural equation modelling suggest that both teacher and parental support are significantly related to adolescent cognitive engagement through their academic efficacy, thus lending support for a full mediation model while peer support was directly related to cognitive engagement.

Significance - Even though parents and teachers played important roles in influencing adolescent cognitive engagement (as suggested by previous studies), this study suggests that the relationship 
was through academic efficacy, which had served as a mediating variable. One of the contributions of this study is that its findings supported the inclusion of student motivational beliefs in explaining the relationship between support factors and engagement. This study had also examined the unique contribution of emotional support. Additionally, it was found that research should not disregard the importance of peers in promoting cognitive engagement directly.

Keywords: Social support, cognitive engagement, self-efficacy, social cognition.

\section{INTRODUCTION}

Schools have always shown great interest in two important aspects of education - academic performance and engagement. As a matter of fact, in recent years there has been a growing interest among not only researchers and educators, but also policy makers on the topic of school engagement. This is because engaging students in their learning is viewed as a way to reduce "low levels of academic achievement, high levels of student boredom, disaffection and high dropout rates" (National Research Council and Institute of Medicine, as cited in Fredericks, Blumenfeld and Paris, 2004), especially in developed, urban societies.

In Malaysia, newspapers had highlighted disturbing reports about hundreds of teenagers between the ages of 14 and 18 living on the streets, and who were being exposed to undesirable underground activities which had thrived in hidden parts of Kuala Lumpur (NST, July 18, 2010). Student disengagement becomes apparent when we begin to see an alarming increase in the number of cases of truancy, gangsterism and bullying (see Ponteng, 2001; Student Crime, 2005; Empat Pelajar SMPs Dibuang Sekolah, 2008). If students are not engaged and do not learn, they will be poorly educated and perhaps will even drop out of school. Certainly, this is not an encouraging scenario in Malaysia. In its National Education Blueprint (NEB) (2006-2010) and further enhanced in the National Key Result Areas (NKRAs), Malaysia aspires to develop its human capital by giving attention to, among others, the value system, disciplinary aspects, character, morals and resilience of the student so as to produce human capital that is competent, innovative, creative and marketable. 


\section{Problem Statement}

The challenges that characterize the passage from childhood to adolescence are indisputably great. While contextual factors within the school and home environment seem important to be investigated, evidence from the literature consistently provides evidence that the transition from primary school to secondary school poses problems to the developing adolescent (Eccles \& Midgley, 1989; Eccles, Wigfield, Midgley, Wigfield, Buchanan, Reuman, \& Flanagan, 1993; Fredericks \& Eccles, 2002). This is echoed in studies (for example, Midgley \& Edelin, 1989; Eccles, Wigfield, Midgley, Reuman, Maclver, \& Feldlaufer, 1993; Wigfield, Eccles, \& Pintrich 1996), which have provided evidence of a mismatch between what the adolescents need and what the environment has to offer. During this developmental age, adolescents seek involvement in decisionmaking and supportive adult relationships. Instead, schools provide social comparison and social control (Eccles \& Midgley, 1989; Feldlaufer, Midgley \& Eccles, 1988; Goodenow, 1993; Kuperminc, Leadbeater, Emmons \& Blatt, 2001). Parents, on the other hand, insist on safety and are less concerned about collective decision making (Gutman \& Eccles, 2007). While there is a mismatch between the needs of adolescents and what the environment has to offer, early adolescents have to also face increasing academic and social stress, which is further compounded by diminishing social support from adults, and an increase in the importance of the peer group (Wenz-Gross, Siperman, Untch \& Widaman, 1997). Empirical studies have shown that an environment that provides a match will promote greater motivational and academic outcomes (Kupermine et al., 2001). Hence, trajectories that emerge during this period of schooling can either lead to success in upper secondary school and graduation, or failure leading to one becoming a school dropout.

Studies on social support in the past have mostly considered the individual roles of the teacher, peer and parents as immediate socializing agents on adolescent engagement, and subsequently achievement; however, to date and to the best of the authors' knowledge, the combined effects of these influences have not been thoroughly examined (Buchanan \& Bowen, 2008) with the exception of a few (see Wentzel, 1998; Chen, 2005). While most studies examined global social support on student achievement outcomes, this study looked exclusively at the unique contribution of academic and emotional dimensions of social support on adolescent 
cognitive engagement. Hence, examining not only the academic dimension of social support, but also the emotional dimension is crucial as Hargreaves, Earl, and Ryan (1996:77) articulated, "one of the most fundamental reforms needed in secondary and high school education is to make schools into better communities of caring and support for young people".

Research on diverse samples of youth have indicated that teacher, peer and parental social support are associated with school behaviour, motivational beliefs, attitudes about school and ultimately school performance (Ahmed, Minnaert, van der Werf, Kuyper, 2010; Wooley \& Bowen, 2007). Despite the importance of a direct relationship between social support from 'significant others' in the students' home and the school environment on student engagement and school achievement, the mediational role of motivational beliefs have seldom been considered. Studies such as those of Eccles (2007), Roeser, Eccles and Sameroff (2000) as well as Wentzel (1998) contend that supportive relationships do influence academic achievement through motivational beliefs such as self-competence, self-efficacy, and subjective value. Thus, the current study examined the direct and indirect relations between parental, teacher and peer support on student cognitive engagement, an engagement which was mediated by academic efficacy, all in one model.

\section{Theoretical Perspective}

This study was guided by Bandura (1986), especially his work on the concept of reciprocal determinism. The concept stems from the view that (a) personal factors in the form of cognition, affect and biological events (b) behaviour (c) environmental influences create interactions that result in a triadic reciprocality. Bandura's Social Cognitive Theory is important in the present research context as it assumes that there is interaction between the person, environment and behaviour. These factors operate as interacting determinants that influence each other bidirectionally. For instance, environmental factors are said to influence personal beliefs, while self-beliefs affect behaviour, and subsequently behaviours impact and change the environment as well as the self-referent thoughts individuals hold. In the context of the present study, whereby the 'environment' which comprised family members exclusively, parents, and the school environment which included teachers and peers, 'person' (efficacy beliefs) and 'behaviour' (cognitive engagement) were examined to see their interrelationships. In a lengthy discussion on social capital 
and its relationship with educational outcomes, McNeal (1999) pointed out that support by adults, especially parents was related to behavioural outcomes rather than cognitive outcomes (for instance, academic achievement). In short, support in the present study was expected to be related to cognitive engagement, which had also been interpreted as a behavioural outcome.

The ecological framework proposed by Bronfenbrenner (1986) was also found useful in the current investigation. This framework has stressed on the importance of social relationships for adolescents across the microsystems such as the home and the school. According to the theory, there are five environmental systems, namely: microsystem, mesosystem, exosystem, macrosystem and chronosystem (ranging from close interpersonal interactions to broad based influences of culture). Within the microsystem, the child has direct contact with the significant people around him, and it is within this microsytem that parent-child, school-home, and peer-child partnerships occur. The reciprocal links can have a strong influence on an individual's psychological and emotional development. Thus, this theoretical perspective offers a holistic approach in understanding the complexity of human development, a development which can be simultaneously affected by a number of interacting contextual factors. The home and school, according to Bronfenbrenner (1986) exert the most influence on the developing child.

\section{Social Support and Engagement}

Researchers basically agree that chronic disengagement can contribute towards low achievement among adolescents (Marks, 2000), to the extent of their dropping out of school (Archambault, Janosz, Morizot, \& Pagani, 2009). As engagement is viewed as a malleable construct that can be altered by the environment (Sinclair, Christenson, Lehr \& Anderson, 2003), a growing number of researchers are interested in studying the construct as a mean to promote achievement. Appleton, Christenson, Kim and Reschly (2006) conclude that contextual factors related to home, school, and peers are facilitators of engagement that influence adolescent support for learning and engagement. According to Fredericks et al., (2004), engagement is a multifaceted construct which encompasses three dimensions, namely cognitive, psychological and behavioural engagement. The present study, however, dealt specifically with a specific type of engagement - cognitive engagement, since the 
relation between social support and cognitive engagement had been largely unexplored. Research has bridged the link between academic self-regulated learning (the highest form of cognitive engagement) and academic success (Pintrich \& DeGroot, 1990). Thus, a wellestablished association between social support and cognitive engagement may set the stage for the development of appropriate interventions in the future.

\section{Social Support and Motivational Beliefs}

Supportive relationships have been linked to a number of motivational beliefs which include among others, self-efficacy, interest and goal orientations (Felner, Aber, Primavera, \& Cauce, 1985; Wentzel, 1998). Bandura (1986) defines self-efficacy as the beliefs about one's capabilities to learn or perform behaviours at designated levels. The belief that an individual holds about his ability and the outcome of his effort influence in great ways how he will behave. According to Bandura, efficacy beliefs depend largely upon early experiences at home. Such self-system is said to provide an individual with the capacity to alter his environment and influence his subsequent performances. Feeling efficacious helps an individual to expend more effort, and to behave in an appropriate manner, which ultimately becomes necessary to maintain high achievement. Additionally, according to Schunk (1996), teacher feedback may influence self-efficacy beliefs while self-efficacy beliefs influence teachers' expectations of the students.

In relation to this, a student's motivational belief may affect his approach to learning activities and academic outcomes (Pintrich, Roeser \& DeGroot, 1994). As such, motivational beliefs are said to affect learning engagement (Linnenbrink \& Pintrich, 2003). Since efficacy can be accessible from, observable in and affected by learning contexts (Lorsbach \& Jinks, 1999), perceptions of support from the home and the school environment may affect efficacy beliefs, which in turn, affect student learning engagement.

\section{PURPOSE OF THE STUDY}

The main purpose of the current investigation was to examine the role of social support providers including parents, teachers and peers in promoting adolescent cognitive engagement. Heeding calls for a more domain specific measurement of self-efficacy (Pajares, 1996) 
as well as social support (Lakey \& Cohen, 2000) and engagement (Fredericks et al., 2004), the present study set out to examine these constructs within ESL classrooms. Its primary concern however, was to examine the role of social support in predicting student cognitive engagement directly or indirectly through academic efficacy. Most of the associations were derived from a review of literature in the area and from existing empirical models.

The following diagram shows the conceptual framework of the present investigation.

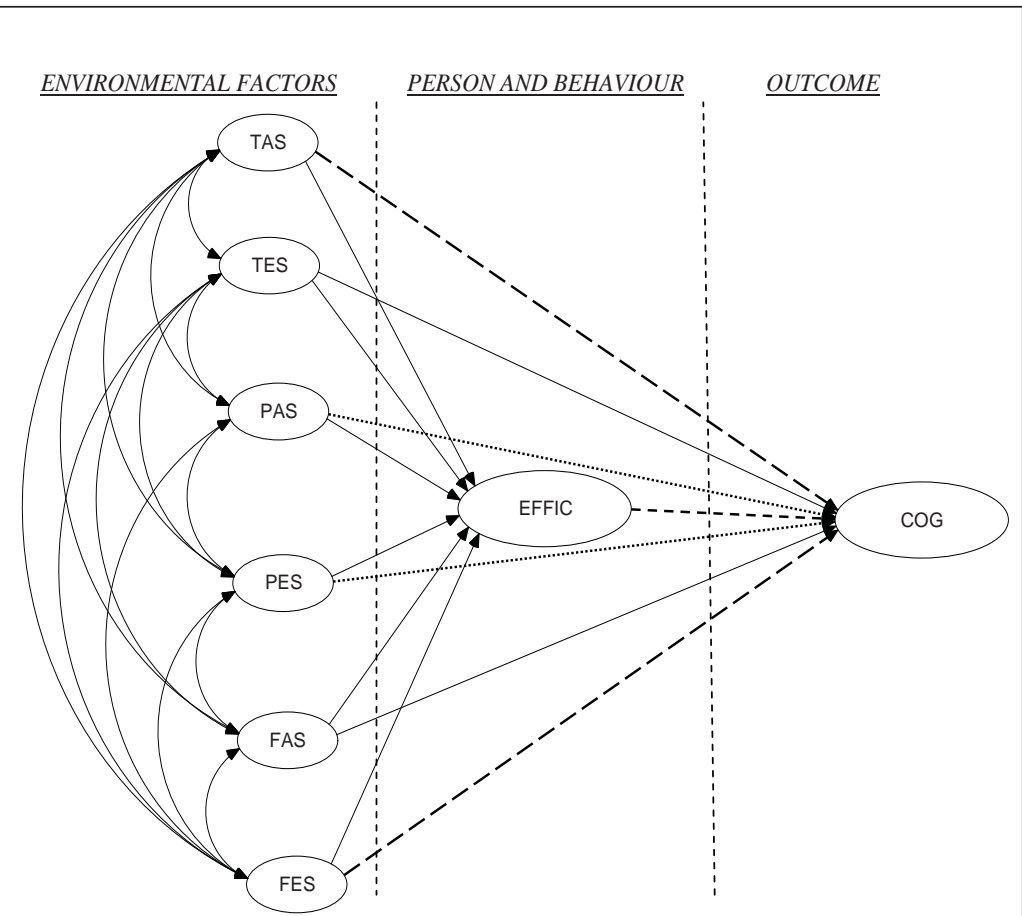

Figure 1. The conceptual framework

Note: TAS=Teacher Academic Support; TES=Teacher Emotional Support; PAS= Parental Academic Support; PES=Parental Emotional Support; FAS=Peer Academic Support; FES= Peer Emotional Support; EFFIC=Academic Efficacy; $C O G=$ Cognitive Engagement

A key question for people in the school system, be it teachers, school personnel, school psychologists and the like is: what are the factors that can best predict adolescent levels of cognitive engagement, since 
knowledge of this may help improve adolescent school functioning. Drawing from the available literature, the researchers hoped to be able to construct a model that could best explain the most variance in adolescent cognitive engagement.

\section{METHODOLOGY}

A total of 450 respondents participated in the study, of which 217 and 233 were male and female respondents respectively. Adolescents (aged between 14 and 16) were chosen as respondents since studies had revealed that it was during this developmental period that adolescents went through a lot of changes within almost every domain of experience. This period had been referred to by many as a period of "storm and stress". Furman and Buhrmester (1992) related this period as the time when youths perceive parents and teachers as less supportive and peer support peaks.

- The subjects came from low-income semi urban community. Eleven schools in one northern state in Malaysia participated in the study. A multistage cluster sampling proposed by Babbie (2007) was utilized. The sampling size was based on Krejcie and Morgan's (1970) sampling size determination. The self-reported survey was in the Malay language. The study utilized the back translation method as proposed by Brislin (1970).

\section{Instrumentation}

The translated Malay version of the cognitive engagement measure (comprising 11 items) was adapted from a study by Rosna, Zahyah, Harshita Aini, Azlina, and Hamida Bee (2006). The psychometric properties (validated through confirmatory factor analysis) of the cognitive engagement scale had been ascertained by Rosna and Azlina (2008) within the Malaysian setting. They further proposed that the multidimensional school engagement scale comprising the three types of engagement can either be used singly or together. The Patterns of Adaptive Learning Survey (PALS) (Midgley, Maehr, Hicks, Roeser, Urdan, Anderman, \& Kaplan, 1996) which consists of five items was utilized to measure academic efficacy beliefs. The social support scale (teacher, parental and peer support) was adapted from a number of established instruments such as the School Climate Survey, Middle School Version (Aber, Meinrath, Johnston, 
Rasmussen \& Gonzales, 2000), Teacher Caring Scale (Muller et al., 1999), Teachers, Parents and Friends Academic Support Scale (Chen, 2005) and Classroom Life Measure (Johnson, Johnson \& Anderson, 1983) as well as self-developed items developed based on the literature review. The social support scale as used in the present study was aimed at extracting the essence of academic and emotional dimensions of support, since the measure was utilized in the school setting. Furthermore, the emotional dimension had not been capitalized in assessing social support, as a large percentage of studies assessing social support had considered global support over the various dimensions of support from significant others (Winemiller, Mitchell, Sutcliff \& Cline, 1993). The final social support scale resulted in a total of nine items each for teacher academic support and teacher emotional support while parental academic and parental emotional support made used of 10 and nine items respectively. Peer academic and emotional support both comprise seven items each, resulting in a total of 51 items for the social support scale. However, in analysing the model, parcelled items were used over individual items as suggested by Little, Cunningham, Widaman and Shahar (2002) since parcelling enhances the stability of parameter estimation and decreases problems in convergence.

The psychometric properties of the instruments were ascertained when all the measures were submitted to Exploratory Factor Analysis (EFA) via SPSS and Confirmatory Factor Analysis (CFA) via AMOS, both softwares were version 16. A reliability analysis was also conducted prior to that. Subsequently, it was found that the instruments all had cronbach alphas of higher than .70 (Hair, Black, Babin, \& Anderson \& Tatham, 2006). Confirmatory factor analysis conducted showed a six-factor model for the social support scales, lending support for a convergent validity of the instruments. Additionally, an expert in the field of educational psychology determined the evidence for construct validity.

\section{RESULTS}

In order to answer the research questions, structural equation modelling became the method of choice for assessing hypothesized structural relations, especially when mediation was involved. First, the measurement properties of each of the constructs were tested. Results showed that the measurement model of each of the 
constructs fitted the data adequately by assessing the goodness of fit indices. Prior to that, Pearson Correlation that was run showed that all the constructs displayed moderate to strong correlations between constructs, and in the expected directions. The highest correlation was between teacher academic support and teacher emotional support $(\mathrm{r}=.68, \mathrm{p}<.001)$, while the lowest correlation was between peer emotional support and cognitive engagement $(r=.20, p<$ $.001)$. The following table presents the correlations between all the constructs under study.

\section{Table 1}

Pearson Bivariate Correlations: Social Support Factors, Academic Efficacy and Cognitive Engagement

\begin{tabular}{lllllllll}
\hline 1 & 2 & 3 & 4 & 5 & 6 & 7 & 8 \\
\hline
\end{tabular}

\begin{tabular}{lllllllll} 
TAS & 1.00 \\
TES & $.68(* *)$ & 1.00 \\
PAS & $.39(* *)$ & $.28(* *)$ & 1.00 & & & & & \\
PES & $.27(* *)$ & $.26(* *)$ & $.57(* *)$ & 1.00 & & & & \\
FAS & $.32(* *)$ & $.31(* *)$ & $.32(* *)$ & $.24(* *)$ & 1.00 & & & \\
FES & $.22(* *)$ & $.28(* *)$ & $.25(* *)$ & $.25(* *)$ & $.67(* *)$ & 1.00 & & \\
COG & $.27(* *)$ & $.24(* *)$ & $.31(* *)$ & $.32(* *)$ & $.28(* *)$ & $.20(* *)$ & 1.00 & \\
\hline EFF & $.30(* *)$ & $.22(* *)$ & $.37(* *)$ & $.38(* *)$ & $.23(* *)$ & $.20(* *)$ & $.28(* *)$ & 1.00 \\
\hline Mean & 4.33 & 4.07 & 4.44 & 4.80 & 4.10 & 3.54 & 4.13 & 4.28 \\
SD & .78 & .88 & .80 & .81 & .92 & .86 & .61 & .94 \\
\hline
\end{tabular}

Note: ** Correlation is significant at the 0.01 level (2-tailed)

TAS=Teacher Academic support; TES=Teacher emotional Support, PAS=Parental Academic support; PES=Parental Emotional support; FAS = Peer Academic support; FES=Peer Emotional Support; COG=Cognitive Engagement; EFF= Academic Efficacy

The measurement model for all constructs under study was further submitted to CFA. The model derived from CFA showed adequate fit to the data. The fit indices were as follows: $\chi^{2}(340, \mathrm{~N}=450)$ $=620.34, \mathrm{p}<.001,\left(\chi^{2} / \mathrm{df}=1.82\right)$ while TLI and CFI coefficients 
were well above .90. The values of RMSEA and SRMR were .04 and .03 respectively. All $\beta$ weights were significant at $p<.001$ with loading values ranging from .58 to .87 ( $\mathrm{t}$ values of 10.58 to 22.37). Discriminant validity was also established when none of the disattenuated correlations between the constructs exceeded .90 .

The overall measurement model was then submitted to structural equation modelling. Subsequently, the model fitted the data adequately with the incremental indices of TLI and CFI all above .90 (.96 and .97 respectively) whilst the value of RMSEA was adequate (RMSEA $=.04$ with $90 \%$ lower bound $=.04$ and upper bound $=.05$ ). The simplified diagram below shows the structural model.

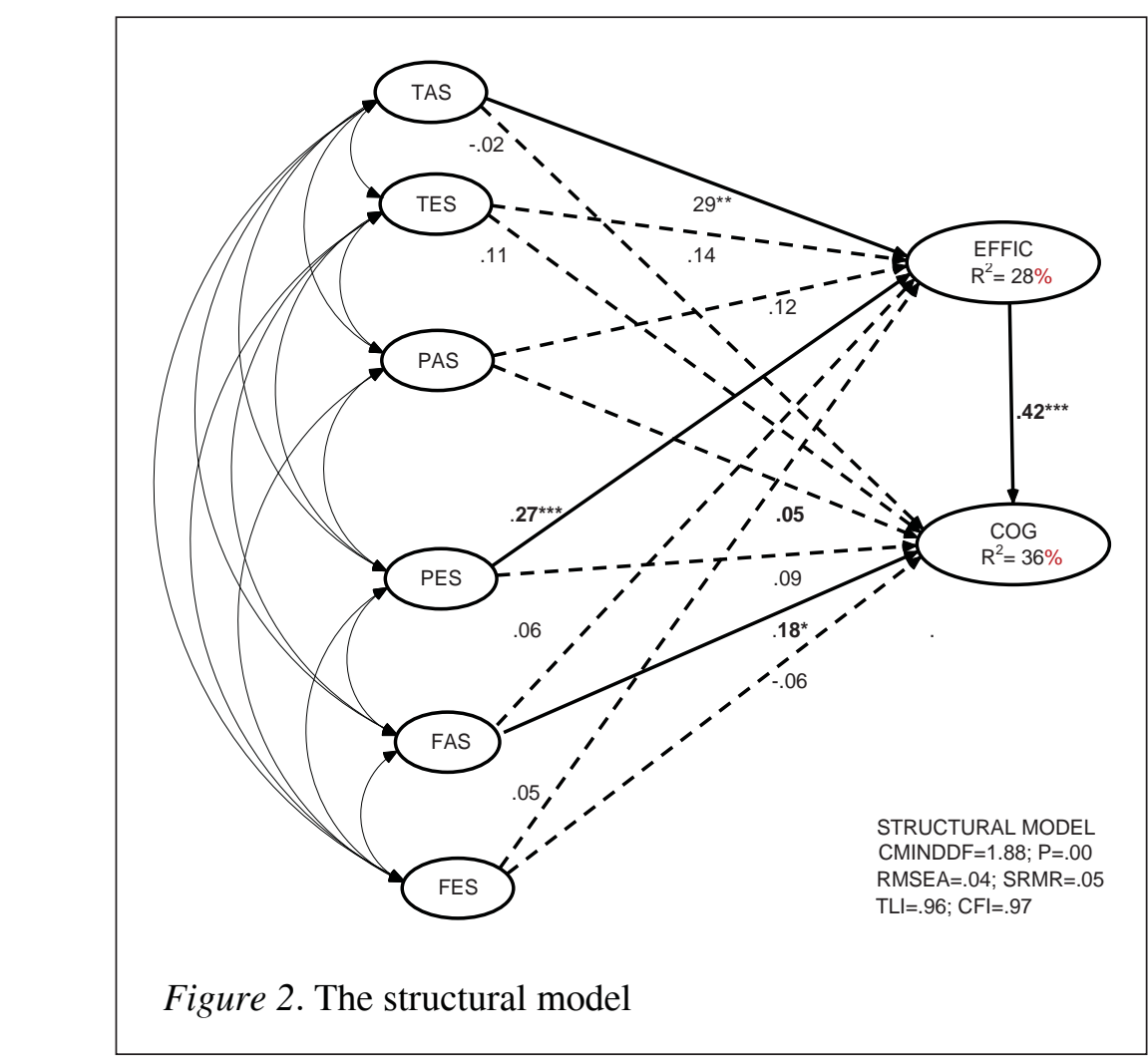

Note: TAS=Teacher Academic support; TES=Teacher emotional Support, PAS= Parental Academic support; PES=Parental Emotional support; FAS = Peer Academic support; FES= Peer Emotional Support; EFFIC=Academic Efficacy; $C O G=$ Cognitive Engagement significant paths

non-significant paths 
The testing of the structural equation modelling were attempts to answer the following research questions:

RQ1: Are perceived support from teachers, parents and peers (academic and emotional dimensions) directly related to student cognitive engagement?

The findings revealed that the only direct relationship between perceived support factors and cognitive engagement was the relationship between peer academic support (FAS) and cognitive engagement (COG), $(\beta=.18, \mathrm{t}=2.03, \mathrm{p}<.05)$. Thus, it could be concluded that only peer academic support was significant as it was positively related to cognitive engagement directly.

RQ2: Does academic efficacy mediate the relationships between perceived support factors and cognitive engagement, which in turn, is related to student cognitive engagement?

Results provided the following findings. Teacher academic support (TAS) $(\beta=.29, \mathrm{t}=2.72 \mathrm{p}<.01)$, and parental emotional support $(\mathrm{PES})(\beta=.27, \mathrm{t}=3.69, \mathrm{p}<.001)$ each influenced student academic efficacy, which in turn, affected their cognitive engagement $((\beta=.42, t=6.55, p<.001)$. In other words, academic efficacy mediated the relationships between teacher academic support - and cognitive engagement as well as between parental emotional support and cognitive engagement. However, both peer academic $(\beta=.06, t=.63, p>.05)$ and peer emotional support $(\beta=.05, t=.54$, $\mathrm{p}>.05)$ as well as teacher emotional support (TES) and parental academic support (PAS) (with $\beta$ values of $.14, t=1.62, p>.05$ and $\beta=.12, t=1.43, p>.05$ respectively) did not have any influence on academic efficacy. The variance explained by the predictor variables on the endogenous variables, i.e. academic efficacy and cognitive engagement respectively are $28 \%$ and $36 \%$.

\section{DISCUSSION}

This section highlights the findings of the present study. The study showed that peer academic support was the only path that had a significant contribution to student cognitive engagement directly. This could be explained in terms of a peer observation model, in this case, a student observing another peer. According to Zimmerman and 
Martinez-Pons (1986), students can learn the self-regulated learning process through the observation of a model. This is especially true during class discussions or classroom interactions - particularly when less able students are grouped with more competent students, modelling will most likely take place. A student may observe his peer's self-regulated behaviour and diligence, and may have the inclination to imitate (Berndt, 1999). Social assistance that normally entails requesting help from others during class is a critical strategy for self-regulated learning (Zimmerman \& Maratinez-Pons, 1986). Hence, student academic help which touches on how to deal with academic related tasks in the classroom can help other students sustain their cognitive engagement in the classroom. However, the insignificant indirect effect of peer support on cognitive engagement through efficacy belief may suggest that the quality of friendship is important for adolescents, as suggested by Berndt (1999). According to Berndt (1999), when the quality of friendship is high, positive or negative outcomes should entail. Friendship high in rivalry may have resulted in the insignificance of classmates' emotional support on cognitive engagement indirectly.

The present investigation had also highlighted teacher academic support and parental emotional support as the two salient social supports which had indirect relationships with cognitive engagement. As such, self-efficacy served as a mediating variable in the relationship. However, not all predictor variables were mediated by self-efficacy in the relationships. For example, teacher emotional support and parental academic support as well as peer academic and emotional support did not matter in the relationships. The significance and insignificance of the findings may be attributed to a number of reasons. Firstly, the unique contribution of teacher academic support on academic efficacy (which is a form of student motivational belief) confirmed a recent study which suggested that teachers could play significant roles in enhancing student motivational beliefs, which in turn, affected student achievement (Ahmed, Minnaert, van der Werf \& Kuyper, 2010).). The powerful roles of teachers can actually be translated into feelings of selfcompetence and a sense of security amongst adolescents within the classroom environment, enabling these adolescents to utilize strategies which will lead to their cognitive engagement.

Secondly, the finding affirmed the significance of parental support on student efficacy beliefs, thus reinforcing the mediational role of efficacy beliefs as suggested by Ahmed et al. (2010) and 
Parsons, Adler and Kaczala (1982). As such, the mediational role of efficacy beliefs in this study provided further evidence on the importance of parental support in adolescent academic outcomes. Conversely, the insignificant contribution of parental academic support on efficacy beliefs might be attributed to the low socioeconomic status (SES) of the parents in this study. These parents might thus, not possess the educational expertise to provide the appropriate educational guidance and assistance for their children. They would be unable to boost their children's efficacy beliefs about their competency in the English language.

Bearing in mind that school outcomes can be enhanced when students feel supported, school stakeholders (the principals, teachers and counsellors) need to first determine what kinds of support are indeed needed by the adolescents in their respective schools, and how dissatisfied these adolescents are with the present school or classroom environment. Interventions within the school system should focus on making teachers aware of the needs of adolescents, and provide the staff with the necessary training on how to provide for such needs. Thus, efforts in building school support programmes should be made in such a way that these programmes are easily accessible. Additionally, teachers should be sensitised to the paramount importance of instilling high efficacy beliefs in their students. Thus, instructional procedures that draw on or enhance - student efficacy beliefs may hold promise for both younger and - older adolescents.

5

Two significant findings from the present investigation are noteworthy. First, adolescent efficacy belief, which is domain specific to the English language classroom, is a plausible mediating variable between social support providers namely teachers and parents on student cognitive engagement. To the best of the authors' knowledge, previous studies have not considered the roles of efficacy in mediating the effects of social support on adolescent cognitive engagement in the classrooms. As such, more cross-cultural studies are deemed necessary (Rosna Awang-Hashim, O'Neil, \& Hocevar, 2002) in order to affirm its mediational role. Although speculative in nature, other variables such as emotional engagement may be a significant mediator, particularly for peer support and teacher support factors. 
Secondly, the dimensions of social support (academic and emotional dimensions) had been used in place of global support in order to see the unique contribution of emotional support on student outcomes. As such, even though the correlations between emotional and academic dimensions appeared to be high in this study, the association was still below .90 , which negated the possibility of multicollinearity amongst the constructs under study, and instead provided support for the orthogonality of each dimension. Hence, the study managed to capture the essence of the academic and emotional dimensions of social support.

Thirdly, as had been delineated in a number of studies, as children moved into adolescence, there was a propensity for them to seek independence from parents and develop closer ties with their peers. This study has further provided evidence that parental support, particularly parents' emotional support, still plays a significant role in promoting adolescents educational outcomes in addition to the role played by teachers.

\section{IMPLICATIONS AND FUTURE STUDIES}

The study lends support to Social Cognitive Theory which assumes that the environment plays a pivotal role in influencing adolescent engagement within the classroom while their efficacy beliefs play a regulatory role within the social, psychological and contextual network where personal agency operates. Perception of oneself as an active agent improves one's efficacy beliefs, and in turn, affects one's cognitive engagement. If student efficacy belief can operate to influence engagement and ultimately, performance, then educational efforts and teaching strategies should be tailored towards enhancing the self efficacy beliefs of these adolescents.

It is recommended that future studies make an effort to differentiate between providers of support, particularly parental support. Fathers and mothers in Malaysia may provide differential forms of support to their adolescents depending on their educational background and SES. With regard to peer support, studies should look into affective engagement as a mediator in the relationship between peer support and cognitive engagement. This is because studies have shown that having a sense of belonging in the school is a motivating factor for students to stay in school and succeed (Archambault et al, 2009; Jennings, 2003). 
As with all studies that utilized cross-sectional data, caution should be exercised when interpreting the findings, as these interpretations preclude causality inferences. It is recommended that more longitudinal studies be carried out to look into the aspect of causal connections.

\section{REFERENCES}

Aber, M. S., Meinrathm, S. D., Johnston, J., Rasmussen, A.E., \& Gonzales, A. (2000). School climate survey: Middle School Version. Champaign, IL., University of Illinois at UrbanaChampaign.

Ahmed, W., Minnaert, A., van der Werf, G., \& Kuyper, H. (2010). Perceived social support and early adolescent achievement: The mediational roles of motivational beliefs and emotions. Journal of Youth Adolescence, 39, 36-46.

Appleton, J. J., Christenson, S. L., Kim, D., \& Reschly, A. L. (2006). Measuring cognitive and psychological engagement: Validation of the student engagement instrument. Journal of School Psychology, 44, 427-445.

Archambault, I., Janosz, M., Morizot, J., \& Pagani, L. (2009). Adolescent behavioural, affective, and cognitive engagement in school: Relationship to dropout. Journal of School Health, 79(9), 408-415.

Babbie, E. ( 2007). The practice of social research (11th ed.). Singapore: Thomson Learning.

Bandura, A. (1986). Social foundations of thought and actions: A social cognitive theory. Englewood Cliffs, N.J.: Prentice Hall. Bandura, A. (1997). Self-efficacy: Toward a unifying theory of behaviour change. Psychological Review, 84, 191-215.

Berndt, T. J. (1999). Friends' influence on student adjustment to school. Educational Psychologist, 34, 15-28.

Brislin, R. W. (1970). Back translation for cross-cultural research. Journal of Cross-Cultural Psychology, 1(3), 185-216.

Bronfenbrenner, U. (1986). Ecology of the family as a context for human development research perspectives. Developmental Psychology, 22(6), 725-742.

Buchanan, R.L., \& Bowen, G.L. (2008). In the context of adult support: The influence of peer support on the psychological well-being of middle-school students. Child Adolescent Social Work Journal, 25, 397-407. 
Chen, J.J. (2005). Relations of academic support from parents, teachers, and peers to Hong Kong adolescents' academic achievement: The mediating role of academic engagement. Genetic, Social and General Psychology Monographs, 131(2), 77-127.

Eccles, J. S. (2007). Families, schools, and developing achievement related motivations and engagement. In J. E. Grusec \& P. D. Hastings (Eds.), Handbook of socialization (pp. 665-691). New York, NY: The Guilford Press.

Eccles, J., Jacobs, J., \& Harold, R. (1990). Gender role stereotypes, expectancy effects, and parents' socialization of gender differences. Journal of Social Issues, 46(2), 183-201.

Eccles, J., Lord, S., \& Midgley, C. (1991). What are we doing to early adolescents? The impact of educational contexts on early adolescents. American Journal of Education, 99, 521-542.

Eccles, J., \& Midgley, C. (1989). State environment fit: Development appropriate classrooms for young adolescents. In C. Ames \& R. Ames (Eds.), Research on motivation in education: Vol. 3, goals and cognitions (pp. 13-44). New York: Academic Press.

Eccles, J., Wigfield, A., Midgley, C., Reuman, D., Maclver, D., \& Feldlaufer, H. (1993). Negative effects of traditional middle schools on student motivation. The Elementary School Journal, 93, 553-574.

Eccles, J., Wigfield, A., Midgley, C., Wigfield, A., Buchanan, C.M., Reuman, D., \& Flanagan, C. (1993). Development during adolescence: The Impact of stage-environment fit on young adolescent experience in schools and families. American Psychologist, 48, 90-101.

Empat Pelajar SMPs dibuang sekolah. (2008, October, 29). Berita Harian, p.5.

Felner, R. D., Aber, M. S., Primavera, J., \& Cauce, A. M. (1985). Adaptation and ulnerability in high-risk adolescents: An examination of environmental mediators. American Journal of Community Psychology, 13, 365-379.

Fredericks, J. A., Blumenfeld, P. C., \& Paris, A. H. (2004). School engagement: Potential of the concept, state of the evidence. Review of Educational Research, 74(1), 59-109.

Fredericks, J. A., \& Eccles, J. (2002). Children's competence and value beliefs from childhood through adolescence. Developmental Psychology, 38(4), 519-533. 
Feldlaufer, H., Midgley, C., \& Eccles, J. S. (1988). Student, teacher, and observer perceptions of the classroom environment before and after the transition to junior high school. Journal of Early Adolescence, 8, 133-156.

Furman, W., \& Buhrmester, D. (1992). Age and sex differences in perceptions of networks of personal relationships. Child Development, 63(1), 103-115.

Goodenow, C. (1993). Classroom belonging among early adolescent students: Relationship to motivation and achievement. Journal of Early Adolescence, 13, 21-43.

Gutman, L.M., \& Eccles, J. (2007). Stage-environment fit during adolescence: Trajectories of family relations and adolescents outcomes. Developmental Psychology, 43, 522-537.

Hair, J. F., Black, W. C., Babin, B. J., Anderson, R. E., \& Tatham, R. L. (2006). Multivariate Analysis (6th ed.). Upper Saddle River, NJ: Prentice-Hall.

Hargreaves, A., Earl, L., \& Ryan, J. (1996). Schooling for change: Reinventing education for early adolescents. Bristol, PA: Falmer.

Jennings, G. (2003). An exploration of meaningful participation and caring relationships as contexts for school engagement. California School Psychologist, 8, 43-52.

Johnson, D.W., Johnson, R., \& Anderson, D. (1983). Social interdependence and classroom climate. Journal of Psychology. 114, 135-142.

Kids on the Street. (2010, July 18) . New Straits Times, p.1

Krejcie, R.W., \& Morgan, D.W. (1970). Determining sample size for research activities. Educational and Psychological Measurement, 30, 608-619.

Kuperminc, G.P., Leadbeater, B.J., Emmons, C., \& Blatt, S.J. (2001). School social climate and individual differences in vulnerability to psychopathology among middle school students. Journal of School Psychology, 39(2), 141-159.

Lakey, B., \& Cohen, S. (2000). Social support theory and measurement. In S. Cohen, L. G. Underwood, \& B. H. Gottlieb (Eds.), Social support measurement and intervention: A guide for health and social scientists (pp. 29-52). New York, NY, US: Oxford University Press.

Little, T.D., Cunningham, W. A., Shahar, G., \& Widaman, K.F. (2002). To parcel or not to parcel: Exploring the question, weighing the merits. Structural Equation Modeling, 9, 151173. 
Linnenbrink, E. A., \& Pintrich, P.R. (2003). The role of selfefficacy beliefs in student engagement and learning in the classroom. Reading and Writing Quarterly, 19, 119-137.

Lorsbach, A. W., \& Jinks, J. L. (1999). Self-efficacy theory and learning environment research. Learning Environments Research, 2, 157-167.

Marks, H. M. (2000). Student engagement in instructional activity: Patterns in elementary, middle and high school years. American Educational Research Journal, 37, 153-184.

McNeal, R.B., Jr. (1999). Parental involvement as social capital: Differential effectiveness on science achievement, truancy, and dropping out. Social Forces, 78, 117-144.

Midgley, C., \& Edelin, K.C. (1998). Middle school reform and early adolescent well-being: The good news and the bad. Educational Psychologist, 33, 195-206.

Midgley, C., Feldlaufer, H., \& Eccles, J.S. (1989). Student/teacher relations and attitudes toward mathematics before and after the transition to junior high school. Child Development, 60, 981-992.

Midgley, C., Maehr, M.L., Hicks, L., Roeser, R., Urdan, T., Anderman, E.M., \& Kaplan, A. (1996). Patterns of adaptive learning survey (PALS). Manual. Ann Arbor: University of Michigan.

Midgley, C, Kapan, A., Middleton, M., Maehr, M.L., Urdan, T., Anderman, E., \& Roeser, R.W. (1998). Development and validation of scales assessing student achievement goal orientations. Contemporary Educational Psychology, 23, 113-131.

Midgley, C., Maehr, M.L., Hruda, L.Z., Anderman, E., Anderman, L., \& Freeman, K. E. (2000). Manual for the patterns of adaptive learning scales (PALS). Ann Arbor: University of Michigan.

Muller, C. (1998). Gender differences in parental involvement and adolescent mathematics achievement. Sociology of Education, 71(4), 336-356.

Muller, C., Katz, S.R., \& Dance, L.J. (1999). Investing in teaching and learning: Dynamics of the teacher-student relationship from each actor's perspective. Urban Education, 34(3), 292-337.

National Education Blueprint. (2008). Retrieved from http:www. moe.edu.my. 
Pajares, F. (1996). Self-efficacy beliefs in academic settings. Review of Educational Research, 66, 533-578.

Parson, J. E., Adler, T. F. \& Kaczala, C. M. (1982). Socialization of achievement attitudes and beliefs: Parental influences. Child Development, 52, 310-321.

Pintrich, P. R., Roeser, R., \& De Groot, E. (1994). Classroom and individual differences in early adolescent motivation and selfregulated learning. Journal of Early Adolescence, 14, 139-161.

Pintrich, P.R., \& DeGroot, E.V. (1990). Motivational and selfregulated learning components of classroom academic performance. Journal of Educational Psychology, 82, 33-40.

Ponteng: Lokasi dan persekitaran sekolah perlu diteliti. (2001, October 18). Utusan Malaysia, p. 6.

Roeser, R.W., Eccles, J.S., \& Sameroff, A.J. (1998). Academic and emotional functioning in early adolescence: Longitudinal relations, patterns, and prediction by experience in middle school. Developmental and Psychopathology, 10, 321-352.

Roeser, R. W., Eccles, J. S., \& Sameroff, A. J. (2000). School as a context of early adolescent academic and social-emotional development: A summary of research findings. The Elementary School Journal, 100, 443-471.

Rosna Awang-Hashim \& Fauziah Abdul Rahim (2005). Gender differences in motivational orientations, approaches to studying and academic achievement among undergraduates. (Unpublished research report), Sintok, UUM.

Rosna Awang-Hashim, Zahyah Hanafi, Harshita Aini Haroun, Azlina Murad Sani, \& Hamida Bee Abdul Karim. (2006). Socio-psychological determinants of adolescent school engagement (Unpublished IRPA project). Sintok, UUM.

Rosna Awang-Hashim \& Azlina Murad Sani (2008). A confirmatory factor analysis of a newly integrated multidimensional school engagement scale. Malaysian Journal of Learning and Instruction, 5, 21-40.

Schunk, D. H. (1989). Self-efficacy and achievement behaviors. Educational Psychology Review, 1, 173-208.

Schunk, D.H. (1991). Self-efficacy and academic motivation. Educational Psychologist, 26, 207-231.

Schunk, D. (1996). Goal and self-evaluative influences during children's cognitive skill learning. American Educational Research Journal, 33, 359-382. 
Sinclair, M. F., Christenson, S.L. Lehr, C.A., \& Anderson, A.R. (2003). Facilitating student engagement: Lessons learned from check and connect longitudinal studies. California School Psychologist, 8, 29-42.

Student crime on the rise. (2005, August 1). New Straits Times, p. 4. Wentzel, K.R. (1998). Social relationships and motivation in middle school: The role of parents, teachers and peers. Journal of Educational Psychology, 90, 202-209.

Wenz-Gross, M., Siperman, G. N., Untch, A. S., \& Widaman, K. F. (1997). Stress, social support, and adjustment of adolescents in middle school. Journal of Adolescence, 17, 129-15.

Wigfield, A., Eccles, J. S., \& Pintrich, P. R. (1996). Development between the ages of 1 and 25. In D.C. Berliner \& R.C. Calfee (Eds.), Handbook of educational psychology (pp. 148-185). New York: Simon \& Schuster / Macmillan.

Winemiller, D.R., Mitchell, M.E., Sutcliff, J., \& Cline, D.J. (1993). Measurement Strategies in social support: A descriptive review of the literature. Journal of Clinical Psychology, 49, 638-648.

Wooley, M. E. \& Bowen, L. B. (2007) In the context of risk: Supportive adults and the school engagement of middle school students. Family Relations, 56, 92-104.

Zimmerman, B.J., \& Martinez-Pons, M. (1986). Development of structured interview for assessing student use of self-regulated learning strategies. American Educational Research Journal, $23,613-628$.

Zimmerman, B. J., \& Martinez-Pons, M. (1990). Student differences in self-regulated learning: Relating grade, sex, and giftedness to self-efficacy and strategy use. Journal of Educational Psychology, 82, 51-59. 


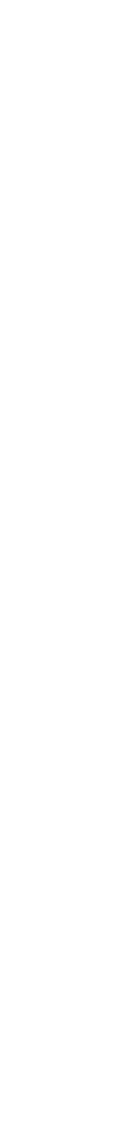

